\title{
Alina Szczurek-Boruta \\ Poland \\ The Condition of Teachers and their Preparation for Work, Implications of Intercultural Education in Poland
}

DOI: 10.15804/tner.2016.44.2.17

\begin{abstract}
What is referred to are the results of nationwide quantitative and qualitative studies conducted in several academic environments. The research constitutes the background against which the condition (the current health, inner intellectual and professional situation) of future teachers is shown as well as the determinants of their preparation for work in multicultural conditions. An authored multisided model of teachers' education has been also presented.

The research approach and interpretation of results have been subordinated mainly to social developmental psychology, the idea of constructivist understanding of individual and social development and intercultural education. In applying the constructivist approach, incorporated into pedagogy from other disciplines, the author's proposal can be seen referring to constructivism with the aim of understanding experiences of adults. It should be emphasized that in the pedagogical literature this mainly concerns the knowledge of small children.

The presented study provides a lot of new information and opens new prospects of further research on the border of intercultural education and general pedagogy, pedeutology, several sub-disciplines of psychology and sociology, as well as of other fields of broadly understood humanities, which can enhance the development of intercultural pedagogy.
\end{abstract}

Keywords: social experiences, learning, identity, constructivism, intercultural education, teacher training 


\section{Introduction}

What currently occurs is a qualitatively different social, cultural and educational reality and basically a different way of human existence in this reality. Transformations of the world triggered off by modernity lead to the disappearance of man's ontological safety and the rise of existential anxiety. Change is a characteristic feature of modernity. The modern world is a world of risk but also of huge potentialities. These selected qualities of modern reality shed new light on the condition of man and they make it topical and indispensable.

One of the essential tendencies determining the education of Polish teachers is the idea of society based on knowledge, dialogue, agreement and collaboration (cf., Report of the Commission to the European Council and Parliament. Implementation of the project of modernization of universities: education, research, innovations). Extended expectations are raised in association with the ideologies of international cooperation, democratization and integration. These are not new ideologies, however, it is now that they can and should indicate a model or models of social life. Whether this will take place depends on successful course and implementation of the ideas of intercultural education - a project which enhances social integration and which can become a model for societies and states in other parts of the world.

The research output concerning intercultural education is quite rich in Poland. In 1992-2015, over 60 publications were issued at the Faculty of Ethnology and Education of the University of Silesia in the series "Edukacja Międzykulturowa" /Intercultural Education/. Studies in this research field have also been regularly published by the University of Białystok, University of Opole and many other academic centres.

In Poland, there are several perspectives in viewing and dealing with intercultural education: anthropological perspective, philosophical-politological one, sociological, and pedagogical. In practice, the anthropological perspective dominates, a standpoint according to which applying in intercultural education the paradigm of "coexistence", dialogue and negotiation (which emphasizes equality of cultures and transculturalism of human needs, aims and aspirations) gives birth to new challenges and consequences in the teacher's work (cf. Szczurek-Boruta 2013, 2014). Teachers' activities may significantly contribute to a better understanding and cooperation among learners (representatives of different nations, cultures, religions), to constructing the reflective project of identity (Gidden's notional category, 2002), the multidimensional identity (Lewowicki's notional category, 2008), the identity of projects (Castells's notional category, 2008). From the standpoint 
of the individual, intercultural education is a chance for: skilful moving about in the modern world, creative designing of one's own life, active citizenship viewed in the European dimension, surviving on the increasingly demanding labour market.

What is assumed here is that social and educational changes depend on the intellectual and professional condition of the teacher. In the situation of the disappearance of the ontological safety of humanity, growing crises and various risks, the teacher's good condition allows for thought, proper choice of lifestyle and the best managing of current situations, threats and problems.

\section{An outline of research issues and presentation of the author's research results}

The undertaken attempt to reflect upon teachers' condition and their preparation for work is grounded in the context of social experiences of future teachers and the changes taking place in viewing teacher education. This complies with the trend towards incorporating learning processes into the standpoint typical of social, cultural and economic processes. The attempted reflections are in harmony with the social perspective of developmental psychology, constructivism (the idea of constructivist understanding of individual and social development framed within the theories of Peter Berger and Thomas Luckmann) and intercultural education. This can facilitate promoting the original socio-pedagogical thought which constitutes contemporary pedeutology. These theories along with the notional theories of social experience and learning create the main theoretical structure. The theoretical background of the issues subjected to reflection clearly highlights the interrelations between intercultural education and the knowledge acquired in the field of pedagogy, psychology, sociology, anthropology and other sciences.

What becomes the starting point for specifying the condition of future teachers is self-reflection on their own learning, constructing the knowledge of themselves and others as well as on teaching.

Applying the constructivist approach to teacher education is associated with the assumption that there is no knowledge independent of the meaning related to experience which is constructed by the learner or a community of learners. The constructivist approach applied in intercultural education comprises, among other things, situational learning (context-dependent learning), the social context of knowledge (learners create and verify their constructs in the dialogue with other individuals and society), and collaboration (a sine qua non for the discussion which negotiates the consensus and verification of knowledge). The perspective 
of social constructionism allows for viewing intercultural education as a dynamic and transcultural strategy of teaching and learning. Learning this perspective is a self-regulating process of handling the conflict between the existing personal models of the world and the information, which come from outside.

What is referred to in this study are research results of the author's extended multivariate studies conducted in Poland in 2011-2014. The participants constituted a representative group of young adults - students of pedagogy. The research model combined the quantitative strategy (auditorium questionnaire) with the qualitative one (group and individual interviews). The quantitative data analysis was carried out with the application of both simple and more complex methods (e.g. factor analysis or data clustering). The basis of the research is made up of the data obtained from 1268 students (1229 women and 39 men). The empirical material, coming from questionnaire studies and 12 narrative interviews in which 84 people took part, was processed by available statistical applications. What constitutes the value of this material is that it drifts apart from fragmentary descriptions and characterizations of the discussed age group living in one selected environment and presents a cross-section of the whole generation - future teachers (the group is representative). This allows for comparisons and generalizations. The empirical material used in this study is interpreted in a way different from those in the author's earlier papers.

A multisided view at the situation and activity of future teachers in Poland indicates their good condition. In the examined group, constructing the reflective project of identity can be noticed. Its foundations are: place of living - place of being rooted ( $85.6 \%$ of the respondents); ability to build bonds (71.6\%); me-others comparisons (67.4\%); existential experiences (46.0\%). Part of the respondents undergoes the process of shaping the multidimensional identity, which harmoniously combines the local, national, European and global dimensions (14.67\%). Shaping of this identity is regarded as one of the major aims of intercultural education. Most of the respondents $(90.1 \%)$ present high pedagogical culture in its three components (behavioural - 88.8\%, emotional - 93.7\%, cognitive $-87.9 \%$ ), which seems to be a positive result of implementing intercultural education and a promising sign of the respondents' willingness to promote the ideas of intercultural education in their future teaching work. The elements of this culture are the following: communication competences, capability of professional development, moral and normative competences, knowledge.

The respondents presented considerable awareness of lifelong education and the need for intercultural education. Future teachers notice the primacy of attitudes and skills over knowledge. Some of the examined students present the 
reflective identity, which might enhance reflective practice and professionalism in their career.

A question is raised of how large the group of teachers presenting this type/ level of (reflective) identity will be and to what extent their work at school will be effective in the implementation of educational teleology (which takes into account the significance of interculturalism, coexistence in the system of values promoted by school, in its culture and in social practice).

Teachers are the fundamental group of representatives of educational transformations as they constitute a specific professional category. This is determined by functions (resulting from both social expectations and individual aspirations) which teachers are to fulfil in the times of creating a new post-industrial social order in the multicultural world. What has been an additional requirement for teachers over many decades is the need for permanent refreshing of their knowledge, self-training and reliable self-assessment.

The results of factor analysis (scree test) allow for distinguishing four dimensions of future teachers' learning. The biggest explanatory power can be attributed to the following factors: the identity of professional role $(11.87 \%)$, experiences in relations with the Other (10.84\%), social participation (7.97\%), and practice $(7.43 \%)$. It is impossible to separate these dimensions as their effects are enhanced when embedded in the socio-cultural context and stimulated by the economic potential. They act in combination, with feedback, ensuring learning efficiency. As a result of this process, individuals construct their own selves and the surrounding world.

Among numerous favourable and unfavourable determinants of future teachers' preparation for work in the ambiguous educational, social and cultural reality, four most significant ones can be distinguished against the background of the research results and their interpretation.

The first determinant is the change of attitude to the Other. Although future teachers are not free from stereotypes and prejudices in perceiving the Other, they also have a positive attitude, openness and multidimensional viewing of the learner as a representative of a different culture. The range of notional categories associated with dissimilarity has enlarged significantly. Apart from traditional notions of race, nationality, ethnicity, religion, and denomination, some new categories appeared which refer to physical (including health and biological-physical dysfunctions), sexual, social, generation (age - the young/the old) and behavioural dissimilarity.

The second field determining teachers' preparation for work in multicultural conditions comprises unique ways of experiencing, feeling and interpreting every- 
day experiences. Candidates for teachers are members of particular cultures. In the process of socialization and education, they collect their individual experiences and generate their specific interpretation rules. They construct their own world out of these experiences and this construction is seen in their behaviour patterns. Learning becomes collecting the experiences which aim at permanent behavioural changes.

The third field is associated with values - regulators of human aims and conduct. They are frequently shaped in long processes and result from collective experiences. Empirically indicated factors - Ideas, Others, $\mathrm{Me}$ - are components of the holistic concept of man. Ideas constitute a model according to which future teachers should shape their behaviour, they precisely specify the values highly appreciated in a particular group - friendship, trust, honesty, kindness, loyalty, solidarity. Me is a subjective image of one's own inner essence. What is most important in social life is what takes place among people, what unites them into consistent groups (social bonds). Teachers notice Others, situate them in space, and become aware of their presence (spatial contact).

The fourth field determining teachers' preparation for work is related to motivation and readiness to act and the fifth is indicated by the economic potential and sociocultural environment. A lot of significance should be attributed in the investigated issues to the environment, which is characterized by a particular dynamic of socio-economic development. The economic potential determines the conditions and standards of life and triggers off new developmental possibilities in groups. An active individual transforms these resources and gives them contents in compliance with his/her own needs.

The quoted research results and their interpretation have become the basis for presenting the author's suggestion for the model of multisided preparation of the teacher for work in multicultural conditions as well as the basis for systematization of phenomena related to learning from Others and teaching Others. On the one hand, this model is a certain notional construct which refers to the real system (the formal and informal educational reality of future teachers); on the other hand, however, it is a set of assumptions applied in the theories which simplify or idealize reality. The elements of the suggested model are the following: (students' individual and cross-group) existential experiences, values, learning and its dimensions, praxeological-methodological principles of organizing academic education, economic conditions, political, ideological and social contexts. Assuming the equality of the distinguished elements and their combined acting - cogeneration, it can be expected that fulfilling the aims resulting from them can facilitate shaping the project of a reflective man (future teacher) and will constitute a significant stage 
in changing the paradigm of the whole education (the model is presented and discussed in the paper: Szczurek-Boruta 2014: 188-211).

\section{Conclusions}

Preparing teachers for work in the multidimensional, multicultural reality has been permanently rooted in the European and Polish educational standards, which indicate competences that a contemporary teacher should possess. These are: competences associated with the process of learning/teaching, including the skill of working in a multicultural and differentiated class, creating favourable conditions for learning, and competences related to shaping learners' attitudes - the skill of creating learners' civil and social attitude (cf.: Report of the Commission to the European Council and Parliament. Improvement of the quality of teachers' education; Rozporządzenie Ministerstwa Nauki i Szkolnictwa Wyższego /The Directive of the Ministry of Science and Higher Education of $4^{\text {th }}$ November 2011 on model teaching effects/).

The conducted studies and analyses provide a lot of information on the condition of Polish teachers and their education, including their preparation for work in culturally diversified environments. The material is thought-provoking and encourages changes of teaching contents and methods in the model of teacher education.

The teacher's work can substantially enhance the growth of learners' intellectual capital as well as the understanding and cooperation between representatives of different nations, cultures, and religions. What should be done while building new democratic societies is not only noticing the significance and responsibility of teachers as intellectual elites in the processes of social integration (in the $21^{\text {st }}$ century dimension) but also and mainly helping them to appropriately play this role. Professional preparation still remains a sine qua non of succeeding in this.

The methodological approach applied in this study involves the thought concerning the condition of young adults, developmental career chances of future teachers, the determinants of their preparation for work in multicultural conditions, and the directions of changes in teacher education. This might help shape the pedagogical sub-discipline of intercultural pedagogy. The research results confirm that, in order to learn more about the processes of change taking place in the micro - and macro-social scale, representatives of educational sciences (with growing frequency) refer to the output of intercultural pedagogy.

It is not possible to prepare teachers for solving all unexpected situations. On many occasions, they will have to manage such situations on their own, showing 
wisdom in using pedagogical knowledge and their own experience. What becomes a necessity is lifelong education as well as broadening both knowledge and competences.

Not everything depends on teachers' education. This social group is involved in many economic and political issues. Problems or reforms of higher education are reflected in the level of teachers' education. There is still a lot to be done to improve and popularize some good examples of the implementation of intercultural education in Polish universities. This is a challenge which should be handled by creating the Polish multicultural society.

The results of the conducted studies have revealed the need for systematic intercultural teaching. There are good experiences in this field in some academic centres in Poland (mainly in Białystok, Cieszyn, Opole). They are discussed in numerous papers published in the series "Edukacja Międzykulturowa" / Intercultural Education/ and particular cases of these activities are described in the journal "Edukacja Międzykulturowa" / Intercultural Education/.

The presented study seems to enhance optimism and the belief that, among contemporary teachers in Poland, there will be many committed to their professional career, to acting for Others (the culturally different) and to the implementation of intercultural education.

\section{References}

Berger, P., Luckman T. (1966). The Social Construction of Reality: A Treatise in the Sociology of Knowledge. New York: Anchor Books.

Castells, M. (2009). The Power of Identity: The Information Age: Economy, Society, and Culture Vol. II. UK: Wiley-Blackwell.

Communication from the Commission to the Council and the European Parliament - Delivering on the modernisation agenda for universities - Education, research and innovation. Brussels, 10.5.2006, http://eur-lex.europa.eu/legal-content/EN/ TXT/?uri=COM:2006:0208:FIN (access: 10.04.2015)

Communication from the Commission to the Council and the European Parliament Improving the Quality of Teacher Education. Brussels, 3.8.2007, http://eur-lex.europa. eu/legal-content/EN/TXT/PDF/?uri=CELEX:52007DC0392\&from=PL (access: 10.04.2015).

Gergen, K. (2001). The Saturated Self, Dilemmas of Identity in Contemporary Life. $2^{\text {nd }}$ ed. New York: Basic Books.

Giddens, A. (1991). Modernity and Self-Identity. Self and Society in the Late Modern Age. Cambridge: Polity Press. 
Lewowicki, T., Grabowska, B., Szczurek-Boruta, A. (eds) (2007). Intercultural Education: Theory and Practice. Toruń: A. Marszałek.

Lewowicki, T. (2012). 'Edukacja międzykulturowa - bilans otwarcia 2012' /'Intercultural education - 2012 opening balance'/ Edukacja Międzykulturowa /Intercultural Education/, No 1, 15-46.

Lewowicki, T. (2008). O podstawowych warunkach pomyślnej pracy nauczycieli w sytuacji wielokulturowości /On the basic conditions of teachers' successful work in the situation of multiculturalism/. In: T. Lewowicki, E. Ogrodzka-Mazur, A. Szczurek-Boruta (eds). Praca nauczyciela $w$ warunkach wielokulturowości - studia i doświadczenia z pogranicza polsko-czeskiego /The teacher's work in multicultural conditions - some studies and experiences from the Polish-Czech borderland/. Cieszyn-Warszawa-Toruń: WEiNoE UŚ, WSP ZNP w Warszawie, A. Marszałek.

Nikitorowicz, J. (2009). Edukacja regionalna i międzykulturowa, międzykulturowa/Regional and multicultural education/, Warszawa: WAiP.

Rozporządzenie Ministerstwa Nauki i Szkolnictwa Wyższego z dnia 4 listopada 2011 w sprawie wzorcowych efektów kształcenia,/The Directive of the Ministry of Science and Higher Education of $4^{\text {th }}$ November 2011 on model teaching effects/ [Journal of Acts 2011, No 253 item 4780].

Szczurek-Boruta, A. (2012). 'Teachers' preparation for work in the environment of multiculturalism - a research report'. The New Educational Review, Vol. 28, No. 2, 167-176.

Szczurek-Boruta, A. (2013a). 'Social experiences of future teachers - a research report'. The New Educational Review, Vol. 34, No. 4, 238-247.

Szczurek-Boruta, A. (2013b). Doświadczenia społeczne w przygotowaniu nauczycieli do pracy $w$ warunkach wielokulturowości /Social experiences in preparing teachers for work in multicultural conditions/. Toruń: WEiNoE UŚ, A. Marszałek.

Szczurek-Boruta, A. (2014a). 'Intercultural Education in Cieszyn Silesia'. American Journal of Educational Research, Vol. 2, No. 3, 154-158. (C) Science and Education Publishing DOI:10.12691/education-2-3-8.

Szczurek-Boruta, A. (2014b). 'Multidimensionality of learning - a report from some studies among candidates for teachers'. The New Educational Review, Vol. 38, No. 4, 211-223.

Szczurek-Boruta, A. (2014c). O przygotowaniu nauczycieli do pracy w warunkach wielokulturowości - konteksty, opinie studentów, propozycje /On preparing teachers for work in multicultural conditions - contexts, students' opinions, suggestions/. Toruń: WEiNoE UŚ, Wyd. A. Marszałek. 